Digitized by the Internet Archive in 2012 with funding from Royal Ontario Museum 


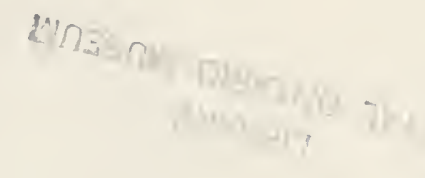





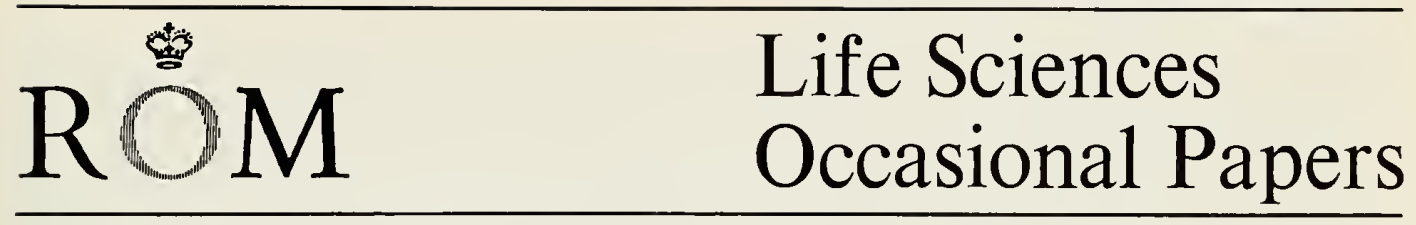

\title{
A New Species of Glauconycteris (Vespertilionidae, Chiroptera)
}

\author{
by R. L. Peterson ${ }^{1}$ and Donald A. Smith ${ }^{2}$
}

In a systematic study of the African genus Glauconycteris Dobson, we have found a series of white-winged specimens that represent a new species that has not been previously described. The genera (or subgenera) Chalinolobus Peters of the Australasian region and Glauconycteris from Africa are closely related as discussed by Dobson (1875, 1878), Miller (1907), Ryan (1966), Hayman (1967), Hayman and Hill (1971), and Koopman (1971). Arguments have been advanced that all species belong to one genus (Chalinolobus), that the two should be considered subgenera, or that generic distinction should be retained for the two taxa, an option that has been widely followed in recent years. We tentatively recognize Glauconycteris as a genus pending the results of our own analysis of variation within each of the African species, now in progress.

We have compared the new taxon with all previously described species of Glauconycteris, but in our opinion, it needs critical comparison only with $G$. argentata (Dobson) and G. variegata (Tomes) as it differs so distinctly either in size or in pelage and wing coloration (or both) from all other known species. We are pleased to name this new species after Mr. Robert Glen, Nairobi, Kenya, who collected the holotype, assisted in the collection of the Uganda series of the new species, and who has been a field companion extraordinaire.

Materials and Methods-A total of 154 specimens of Glauconycteris from Africa, representing eight different species, have been examined and measured in this study (see specimens examined). The specimens examined were from the collections of the following institutions: American Museum of Natural History, British Museum (Natural History), Carleton University Museum of Biology, Carnegie Museum, Field Museum of Natural History, Institut Royal des Sciences Naturelles de Belgique, Los Angeles County Museum, Museum of Comparative Zoology - Harvard, National Museum of Rhodesia, Royal Ontario Museum and United States National Museum. All measurements are given in millimetres and weights in grams. The measurements used follow those as defined by Peterson (1972). Specimens were sorted by sex and age, and 

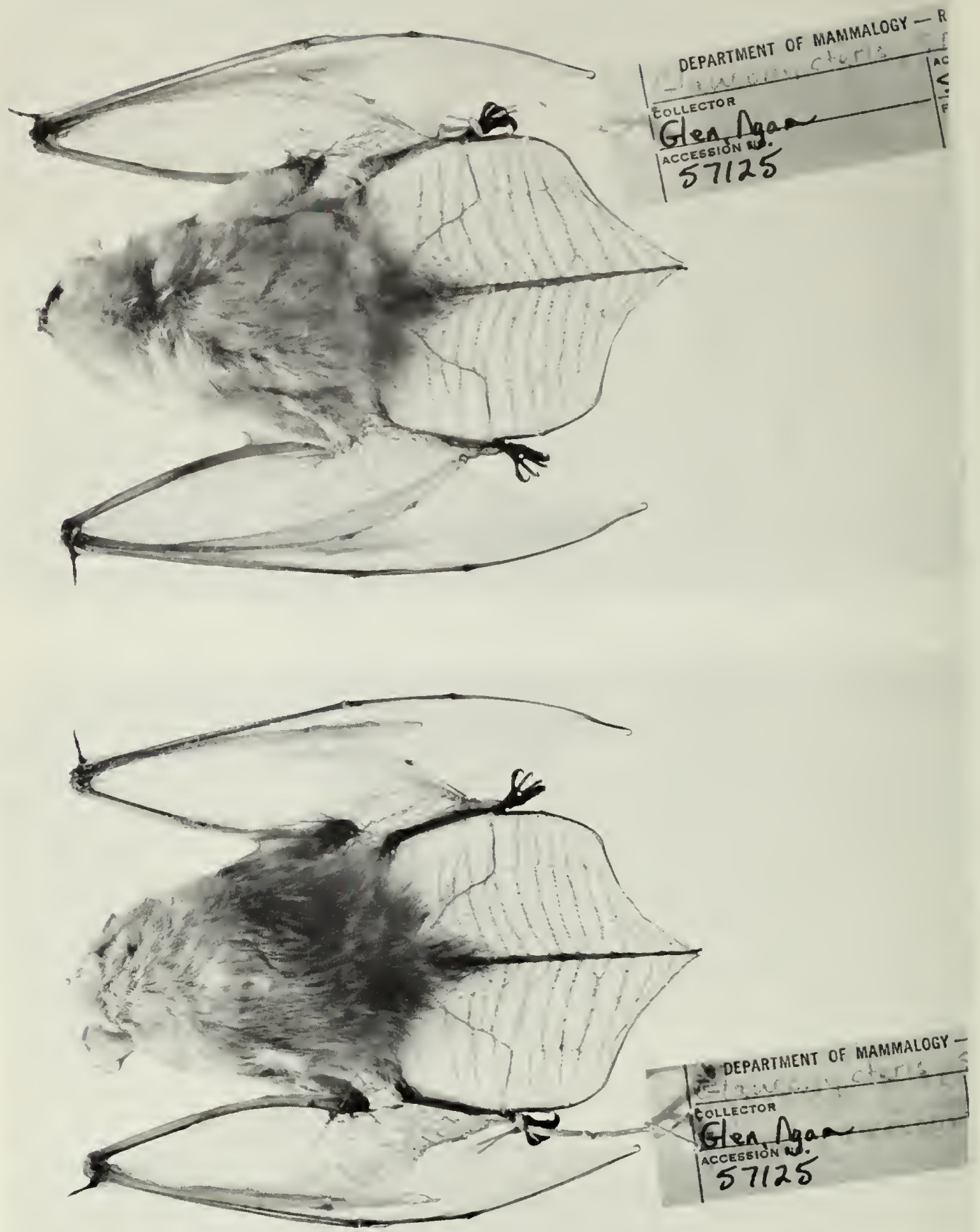

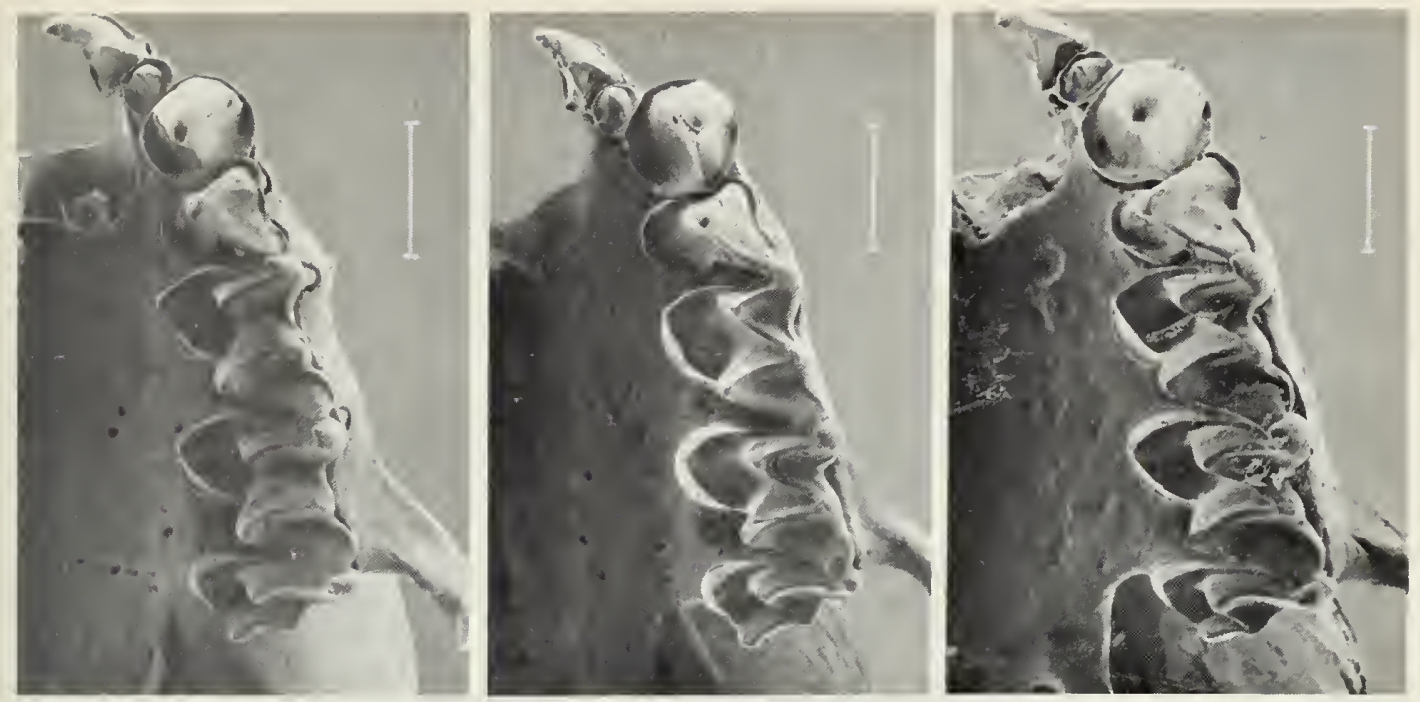

Fig. 2-Upper dentition of three species of Glauconycteris (scale bars $=1 \mathrm{~mm}$ ). Left, G. argentata ROM 50501 o , Kakamega Forest, Kenya (C-M $\left.\mathbf{M}^{3} 4.3 \mathrm{~mm}\right)$. Centre, G. gleni Holotype rom 57125 o, Lomie, Cameroun $\left(\mathrm{C}-\mathrm{M}^{3} 4.75 \mathrm{~mm}\right)$. Right, G. variegata RoM 40141 ô, Budongo Forest, Uganda $\left(\mathrm{C}-\mathrm{M}^{3} 4.8 \mathrm{~mm}\right)$.

the measurements were analyzed using an IBM $/ 370$ computer at the University of Toronto Computer Centre. The means $(\overline{\mathrm{X}})$ and standard deviations (SD) of all characters were calculated for male and female adults, and the differences in character means between species were examined using Student's $t$-test $(P)$. Differences were considered significant at the 0.05 probability level. Selected cranial specimens were photographed with a scanning electron microscope using the technique described by Howden and Ling (1973).

\section{Glauconycteris gleni $\mathbf{s p .} \mathbf{n}$.}

Holotype-ROM 57125, adult female, skin and skull collected 16 June 1970 by Robert Glen and V. Ngam in a tropical forest region near Lomie, Cameroun, $3^{\circ} 10^{\prime} \mathrm{N}, 13^{\circ} 37^{\prime} \mathrm{E}$.

Geographic distribution-Known only from the type locality in Cameroun and from Malabigambo Forest near Sàngo Bay, Masaka District, southern Uganda, $1^{\circ} 05^{\prime} \mathrm{N}$, $31^{\circ} 30^{\prime} \mathrm{E}$.
Diagnosis-Wings and uropatagium white with dark brown pigment outlining the bones of the wings, hind limbs, and tail, the basal portions of the calcars and veinations of the interfemoral membrane, and to a lesser extent the proximal areas of the wings between humeri and hind limbs (Fig. 1). The ears are relativcly large for the genus and have broad tragi. The pelage of the dorsum is quadricoloured with a pale clay-coloured terminal band, a narrow and dark-brown subterminal zone, a pale, buffy, sub-basal zone, and a dark slate-gray basal band. There are no distinct dorsolateral bands of pale pelage as in $G$. argentata. Ventral hairs are bicoloured, with the base gray and the whitish terminal band varying from pure white to a wash of pale yellowish buff. The length of the tibia relative to forearm length is short compared with other species of the genus (Tables 1 and 2).

The size and general shape of the skull of $G$. gleni is similar to that of $G$. variegata but differs from the latter by the combination of a more rounded braincase (equal in

Fig. 1-Dorsal and ventral aspects of the holotype of Glauconycteris gleni rom 57125 ? (total length 100 , forearm length 41.4 ). 


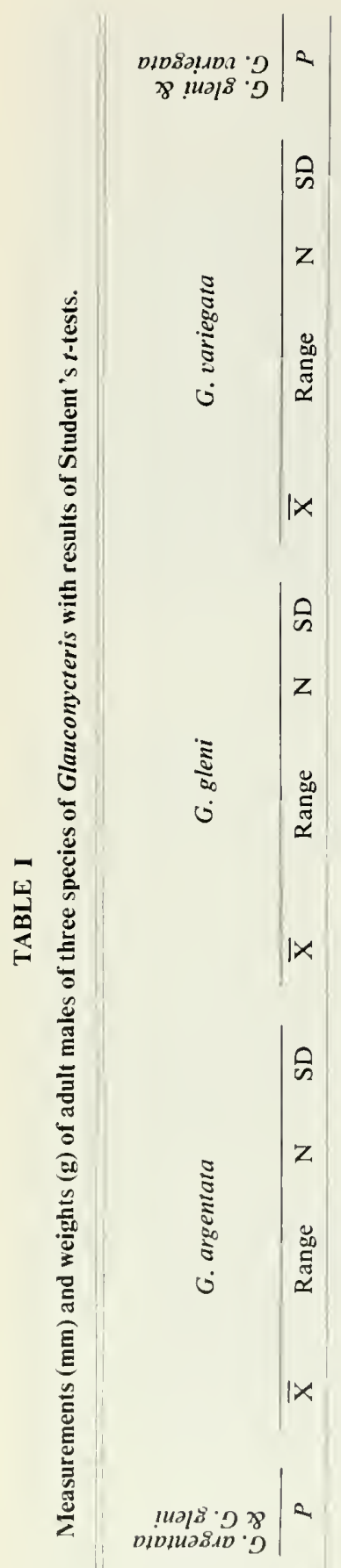

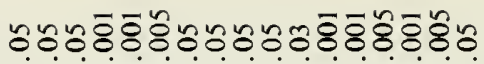

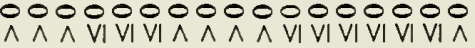

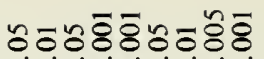
000000000

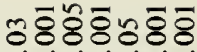
$\wedge \vee \vee \wedge V|V| \wedge V|V| V \mid$

0000000

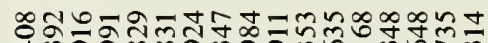

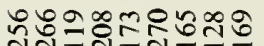

VI VI VI VI VI VI VI rimi0000000000-0000

ல00000000

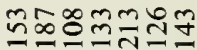
0000000

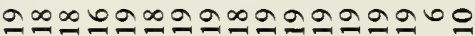

$\because 6 \infty 0$ 으은

$\simeq \infty \infty \infty \infty \infty$

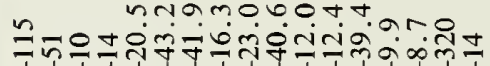

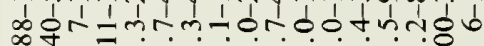
$\infty \min \dot{m}=0$ in

$n \infty .0$.4nnon $\infty-\pi, 4.0 n$

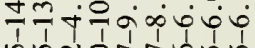
ñndort dón midioninivin पriving vim तmutrmo

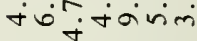

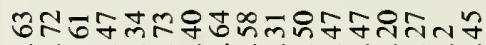
-

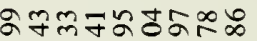

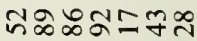

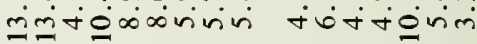

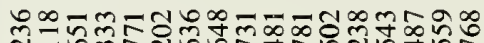

๓ะทํำ

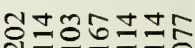

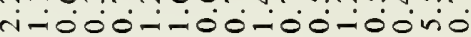
.0.000.00. ம்00்0்

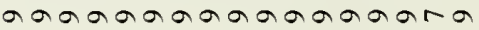

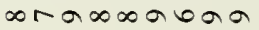

aaraaaa

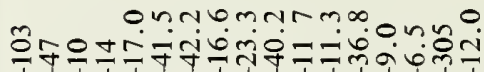

non

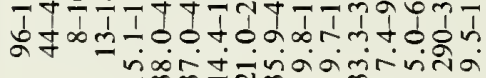

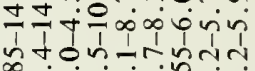
$\infty$ mín-inn mi

o.tonnm í विमेंवंत

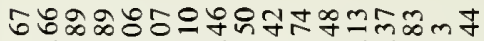
হं

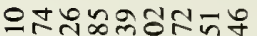

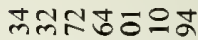

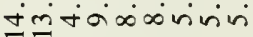

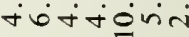

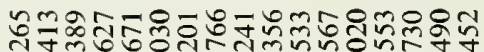
mi-10-10-100-000-

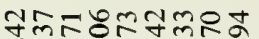

ํํำกำำ 00000000் 000000்

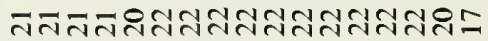

กテี으ำกテี

크ํํํㅠㅇㅠ

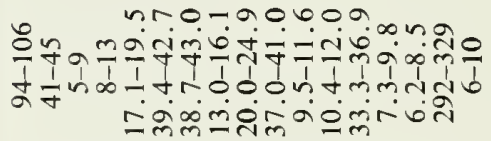

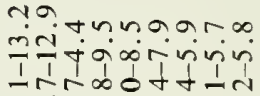

otmuman जi $+\infty 0, \infty, \pi$

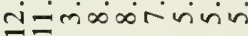
$\dot{\forall} \dot{\nabla} \dot{\forall} \dot{\nabla} \dot{\sim} \dot{ }$

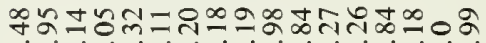
gํำ

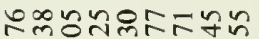

Nㅡ은응

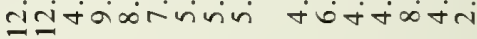

๘๐ 00000000000000000 $\wedge \wedge \mathrm{VI} V|\mathrm{VI} V| \mathrm{VI} V \mid \mathrm{VI} \wedge \wedge \mathrm{VI} \wedge \mathrm{VI} \mathrm{VI} \mathrm{VI} \mathrm{VI}$

\section{ธิธีธธียรินที}

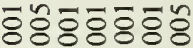
000000000 VI VI VI VI VI VI VI

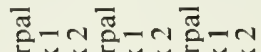
દ

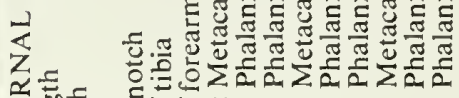

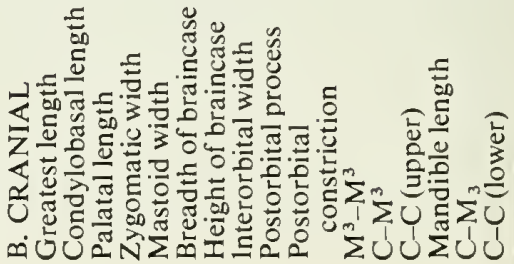




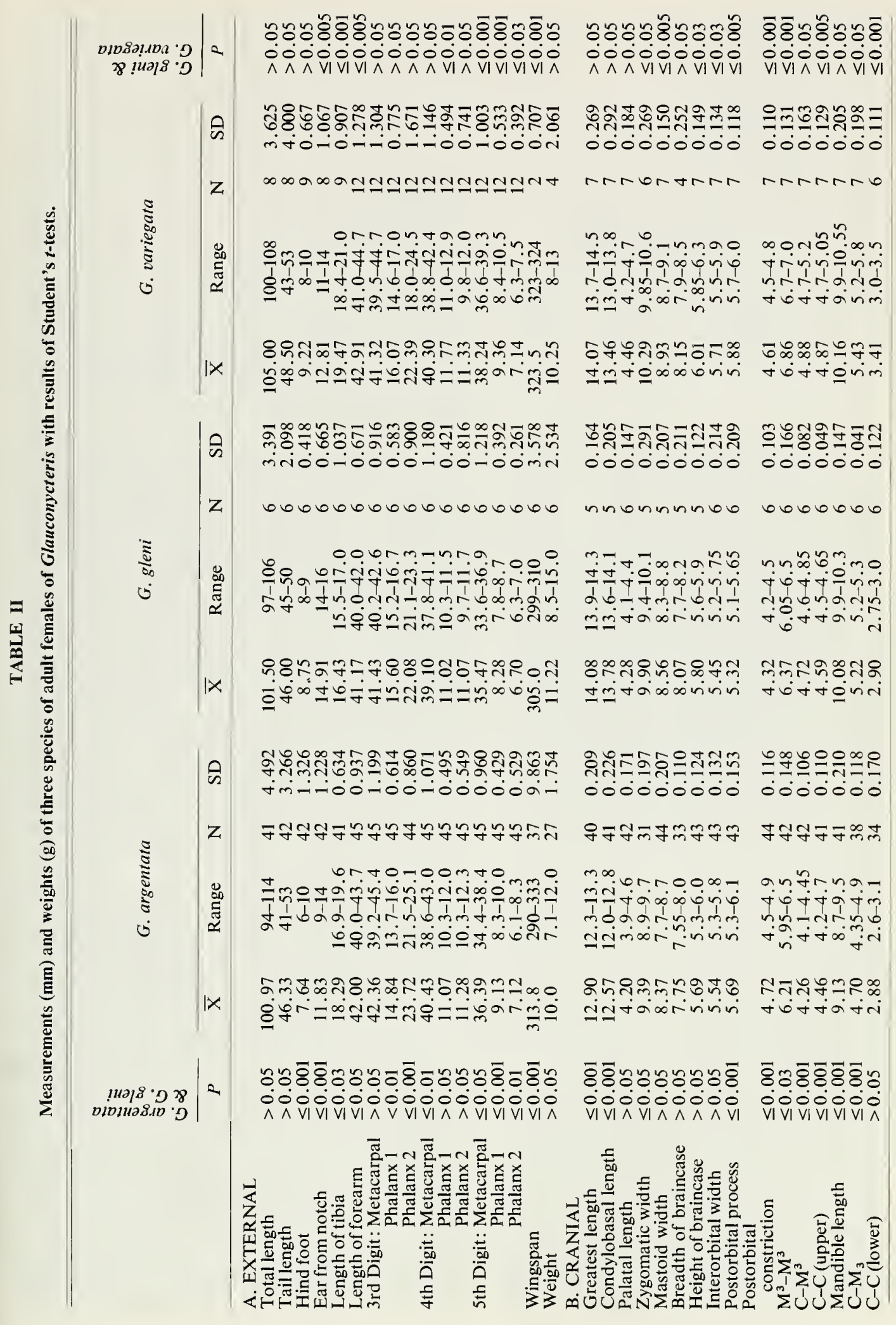



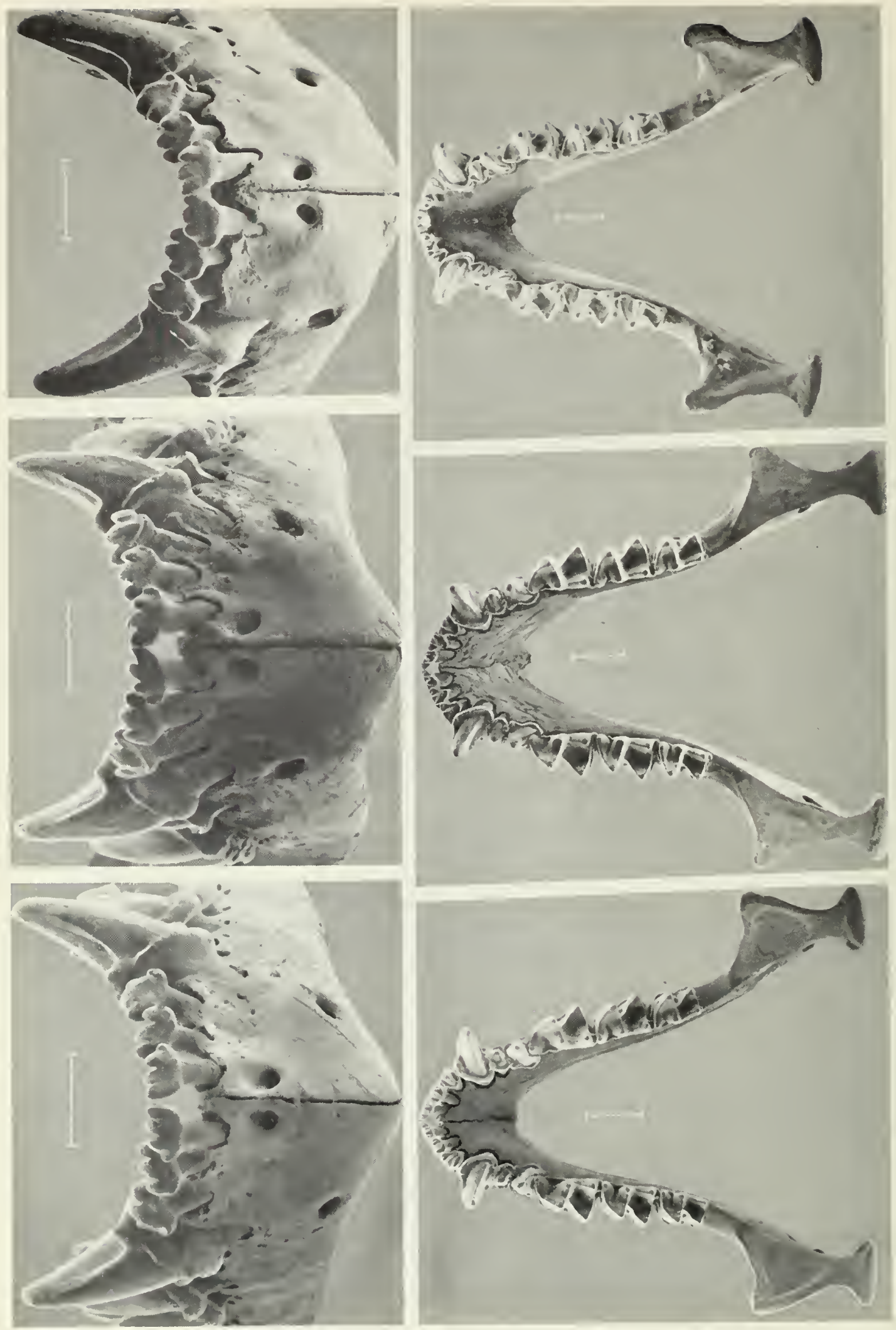
width to that of $G$. variegata) and a narrower mastoid width. The upper inner incisor is usually bilobate, but the development of the posterior lobe varies considerably in individual specimens. The upper premolar has a large hypocone with its lingual margin lying in line with the lingual margins of the canine and the first molar $\left(\mathrm{M}^{1}\right)$ in occlusal view (Fig. 2). The lower incisors are typically trilobate (Fig. 3), but the outer incisor $\left(\mathrm{I}_{3}\right)$ has a well-developed cingulum extending along its anterior surface below the central lobe. The occlusal surfaces of $I_{3}$ and $I_{2}$ are each characterized by the development of a posterior projection of the cingulum to form a heel-like lobe (Fig. 4).

Measurements $(\mathrm{mm})$ of the holotype-External: Total length 100 , tail vertebrae 46 , hind foot 8 , ear 16 , tibia 16.4 , forearm 41.1 , third digit - metacarpal 40.2, first phalanx 15.2 , second phalanx 21.3 , fourth digit metacarpal 37.8, first phalanx 10.9, second phalanx 9.7, fifth digit - metacarpal 34.9, first phalanx 7.8, second phalanx 6.9, wing span 305 , weight 9.25 grams. Skull: Greatest length 14.2, condylobasal length 13.6, palatal length 4.1, zygomatic width 9.9 , mastoid width 8.4 , breadth of braincase 8.2 , height of braincase 5.9, supraorbital process width 5.3, interorbital width (from front) 5.2, postorbital constriction 4.5, width across molars $\left(\mathrm{M}^{3}-\mathrm{M}^{3}\right) 6.4$, length of toothrow $\left(\mathrm{C}-\mathrm{M}^{3}\right) 4.75$, width across upper canines (C-C) 4.6, length of mandible (condylo-incisive) 9.9, length of lower toothrow $\left(\mathrm{C}-\mathrm{M}_{3}\right)$ 5.2, width across lower canines (C-C) 3.0 .

Specimens examined-Glauconycteris gleni sp. n.-The holotype from Cameroun (ROM); plus nine adult and two subadult males, five adult and one subadult females all from Malabigambo Forest near Sango Bay, Masaka District, southern Uganda in the collection of the Los Angeles County Museum. G. argentata (Dobson) - Cameroun, 8; French Congo, 2; Uganda, 6; Kenya, 49; Tanzania, 5. G. variegata (Tomes) Cameroun, 2; Congo, 11; Dahomey, 2; Ghana, 2; Nigeria, 2; Zambia, 2; Sudan, 1; Uganda, 9; Malawi, 1; South Africa (Zululand), 1. G. albogutattus J.A. Allen Cameroun, 1; Congo, 1. G. beatrix Thomas (including $G$. hunteralis J.A. Allen) French Congo, 1; Gabon, 1; Congo, 5; Uganda, 9; Kenya, 6. G. egeria Thomas Cameroun, 1; Uganda, 4. G. machadoi Hayman - Angola, 1. G. superba Hayman Congo, 1; Ghana, 1; Ivory Coast, 1.

Comparisons-Glauconycteris gleni appears morphologically intermediate between $G$. argentata and $G$. variegata. Externally, $G$. gleni resembles a pale-coloured $G$. argentata in the veination of the interfemoral membrane, but markings are considerably darker and the membrane much whiter. G. gleni lacks the dorsolateral bands of pale-coloured pelage on the back, characteristic of $G$. argentata, and the white ventral pelage contrasts sharply with the dark-greyish or brownish coloration of that species. The ear of G. gleni is larger, the tragus is wider, and the tibia is distinctly shorter than in $G$. argentata. G. gleni is significantly larger in 11 of 16 external measurements in both sexes (Tables 1 and 2). In cranial characters, $G$. gleni is significantly larger $(P<$ .001 ) without overlap in measurements of greatest length, condylobasal length, length of toothrow (C-M $\mathrm{M}^{3}$ ), and length of mandible, while the postorbital constriction of $G$. gleni is significantly narrower $(P<$ 0.001 ) in both sexes compared with $G$. argentata (Tables 1 and 2). Of the 16

Fig. 3-Anterior aspect of the lower incisors and canines of the same three specimens shown in Fig. 2 (scale bars $=1 \mathrm{~mm})$. Left, $G$. argentata $(\mathrm{C}-\mathrm{C} 4.5 \mathrm{~mm})$. Centre, G. gleni $(\mathrm{C}-\mathrm{C} 4.6 \mathrm{~mm})$ !

Right, $G$. variegata (C-C $5.0 \mathrm{~mm}$ ).

Fig. 4-Occlusal aspect of lower jaws of the same specimens shown in Fig. 2 (scale bars $=1 \mathrm{~mm}$ ). Left, $G$. argentata (length 9.0, C-M $4.65 \mathrm{~mm}$ ). Centre, G. gleni (length 9.9, C-M $5.2 \mathrm{~mm}$ ).

Right, $G$. variegata (length $9.9, C_{-} M_{3} 5.3 \mathrm{~mm}$ ). 
cranial characters compared, $G$. gleni and $G$. argentata males differed significantly in 12 and females in 10. In dental morphology, specimens of $G$. gleni tended to differ from those of $G$. argentata in having a larger hypoconc on the upper premolar and in the development of the cingula on the anterior surface of the crown of $I_{3}$, as well as on the posterior portion of both $\mathrm{I}_{2}$ and $\mathrm{I}_{3}$ (Figs. 2-4).

When compared with $G$. variegata, $G$. gleni lacks the heavily pigmented markings on the wings, and the markings on the interfemoral membrane are less complex (typically, lines are laterally oriented and anteroposterior orientation of cross-veination is limited). The coloration of the pelage is strikingly different from any known example of $G$. variegata. The dorsal pelage is distinctly quadricoloured instead of tricoloured as in $G$. variegata. Although similar in shape, the ears are longer and the tragi are broader in the new species. The tibia of $G$. gleni is distinctly shorter ( 17.0 or less) than that of $G$. variegata (18.3 or more; see Tables 1 and 2). Of the 16 external measurements (Tables 1 and 2), G. gleni males are significantly smaller in nine and females in eight when compared with $G$. variegata. Although the crania of the two species are similar in size, differences are significant in 13 of the 16 measurements in males and 10 of the 16 in females. In dental morphology, $G$. gleni also differs from $G$. variegata by the shorter first commissure and longer third commissure of $\mathrm{M}^{3}$ and by the greater development of the hypocone of $\mathrm{P}^{4}$ (Fig. 2), as well as by minor differences in the development of the cingula of the lower incisors (Figs. 3 and 4).

Each of the remaining known species of Glauconycteris can be distinguished from $G$ gleni as follows:

$G$. poensis (Gray) - wings pale gray instead of white, general pelage coloration darker, and greatest length of skull less than 13.0 .

G. albogutattus Allen - pclage coloration much darker, wing membranes dark instẹad of white, tibia greater than 17.0, and greatest length of skull shorter (13.1 and 13.2).

$G$. beatrix Thomas - pelage and wing membranes dark, ear shorter (12.0 or less), skull shorter (greatest length, 12.0 or less), and length of mandible less than 9.0.

$G$. egeria Thomas - pelage and wing membranes quite dark combined with striking whitish dorsolateral stripes on the back, larger square-shaped ears, greatest length of skull less than 13.5, and length of mandible less than 9.5 .

G. Machadoi Hayman - darker pelage coloration, as well as wing and interfemoral membranes with sharply defined veinations; otherwise differs in the same way as $G$. variegata.

$G$. superba Hayman - pelage black and white above, black below, forearm length greater than 44.0, greatest length of skull more than 16.0 .

Acknowledgments - We acknowledge the invaluable assistance of many individuals and institutions that have facilitated our studies. We particularly thank Dr. Donald R. Patten of the Los Angeles County Museum for permission to study specimens in his care. Ms. Judy L. Eger, Ms. Liliane Lortie, and Mr. Geoffrey E. Turner provided statistical and other assistance. Dr. H. F. Howden, Department of Biology, Carleton University, permitted our use of the scanning electron microscope and $\mathrm{Mr}$. Lewis Ling took the cranial photographs (Figs 2-4). Messrs. John Williams and Robcrt Glen collected much of the comparative material aided by the financial support and cooperation of Mrs. Noreen Curry. Dr. J. R. Tamsitt critically appraised the manuscript and gave editorial assistance.

This study results from a larger bat research program that has had the financial support of the Canadian National Sportsmen's Show and of the National Research Council of Canada (Operating Grant A-2385). 


\section{Literature Cited}

DOBSON, G. E.

1875 On the genus Chalinolobus, with descriptions of new or little known species. Proc. Zool. Soc. Lond., pt. 3, pp. 381-388.

1878 Catalogue of the Chiroptera in the collection of the British Museum. Printed by Order of the Trustees of the British Museum, London, $567 \mathrm{pp}$.

HAYMAN, R. W.

1967 Chiroptera. In Meester, J. ed. Smithsonian preliminary identification manual for African mammals, pt. 2. Washington, D.C., Smithsonian Institution. 155 pp. Mimeographed.

HAYMAN, R. W. AND J. E. HILL

1971 Chiroptera. In Meester, J. and H. W. Setzer, eds. The Mammals of Africa; an identification manual. pt. 2. Washington, D.C., Smithsonian Institution Press. 73 pp.

HOWDEN, H. F. AND L. E. C. LING

1973 Scanning electron microscopy: Low-magnification pictures of uncoated zoological specimens. Science, vol. 179, no. 4071, pp. 386-388.

KOOPMAN, K. F.

1971 Taxonomic notes on Chalinolobus and Glauconycteris (Chiroptera, Vespertilionidae). Am. Mus. Novit., no. 2451, pp. 1-10.

MILLER, G. S.

1907 The families and genera of bats. Bull. U.S. Natl. Mus. no. 57, pp. 1-282.

PETERSON, R. L.

1972 Systematic status of the African molossid bats Tadarida congica, T. niangarae and T. trevori. Life Sci. Contr. R. Cnt. Mus., no. 85, pp. 1-32.

RYAN, R. M.

1966 A new and some imperfectly known Australian Chalinolobus and the taxonomic status of African Glauconycteris. J. Mammal., vol. 47, no. 1, pp. 86-91. 


Suggested citation: Life Sci. Occ. Pap., R. Ont. Mus.

All manuscripts considered for publication are subject to the scrutiny and editorial policies of the Life Sciences Editorial Board and to review by persons outside the Museum staff who are authorities in the particular field involved.

PRICE: $75 c$

(C) The Royal Ontario Museum, 1973

100 Queen's Park, Toronto, Canada M5S 2C6

PRINTED AT THE UNIVERSITY OF TORONTO PRESS . 





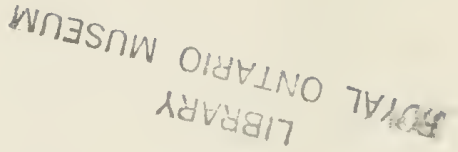$$
\text { WAL ONTARIO MUSEUIA }
$$ 

